\title{
ZnO NANOPARTICLES: GREEN SYNTHESIS, PROPERTIES AND APPLICATIONS
}

\author{
Mariana BUŞIL $\breve{A}$ \\ "Dunarea de Jos" University of Galati, Faculty of Engineering \\ Centre of Nanostructures and Functional Materials-CNMF \\ e-mail: mariana.ibanescu@ugal.ro
}

\begin{abstract}
In this paper, a review, there are presented "Green" routes used in the synthesis of $\mathrm{ZnO}$ nanoparticles because they are more eco-friendly alternatives in comparison with chemical and/or physical techniques. Microorganisms, bacteria, enzymes and plant extracts also allow a controlled synthesis and function as stabilizing or hydrolytic agents. The chemical solvents are toxic, and these methods suffer various disadvantages due to the involvement of high temperature and pressure conditions during nanoparticle synthesis.

The $\mathrm{ZnO}$ nanoparticles are of significant interest as they provide many practical applications in various fields: drugs, cosmetics, textile, electronic and optoelectronic, photocatalysis. The most important application of $\mathrm{ZnO}$ nanoparticles would be as antibacterial agents. The increased surface area and smaller size of these particles make them an ideal antibacterial agent.

In addition to the green synthesis of $\mathrm{ZnO}$ nanoparticles along with their antimicrobial activity the mechanism of this activity was also reviewed. The green synthesis of $\mathrm{ZnO}$ nanoparticles from Azadirachta indica, Aloe vera, Murraya koenigii and Anisochilus carnosus were also highlighted.
\end{abstract}

KEYWORDS: ZnO nanoparticles, green synthesis, eco-friendly, antibacterial activity

\section{Introduction}

A special attention was paid to the green synthesis of metallic nanoparticles using biological material as the reducing and stabilizing agents and due to the utilization of eco-friendly, non-toxic and safe reagents during the biosynthesis process [1-5]. In the green method of chemistry, not only plant extracts are used for controlled and accurate synthesis of several metallic nanoparticles [6]. High active surface due to the small size of nanoparticles are responsible for their behaviour [7, 8]. Green synthesis approaches are gaining interest preventing the high costs and usage of toxic chemicals and harsh conditions for reduction and stabilization [9]. Although, that conventional methods such as reaction of zinc with alcohol, vapor transport, hydro/solvothermal synthesis, precipitation method use less time for synthesizing nanoparticles, they contribute to environmental toxicity because they require toxic chemicals as capping agents. Therefore, the new methods for the nanoparticles synthesis are an ecofriendly alternative and it is cost effective [10-12].

Nanoparticles are synthesized owing to various and unique properties, which facilitate their exploitation in completely unrelated fields, such as, nanodiagnostics, nanomedicine and antimicrobials on one hand [13-22] and luminescence, photocatalytic potential and photodiode on the other [19, 20, 23, 24]. Zinc oxide nanoparticles ( $\mathrm{ZnO}$ NPs) are environmentally friendly, offer easy fabrication and are non-toxic, biosafe and biocompatible, making them an ideal candidate for biological applications [25-26].

Considering this, zinc oxide nanoparticles have been successfully synthesized using biological methods [27-31].

Recently, $\mathrm{ZnO}$ NPs have been used in food packaging materials and various matrices and methods for incorporation of $\mathrm{ZnO}$ into those matrices, which have been reported. $\mathrm{ZnO}$ is incorporated into the packaging matrix, free to interact with the food materials offering preservatory effects [32]. Presently, 
ZnO NPs have found application in sunscreens, paints and coatings as they are transparent to visible light and offer high UV absorption [33] and are also being used as an ingredient in antibacterial creams, ointments and lotions, self-cleaning glass, ceramics and deodorants [34]. $\mathrm{ZnO}$ nanoparticles have been lately tested for their antimicrobial potential and seem to possess both antibacterial and antifungal potential. They are active against both Gram-positive and Gram-negative bacteria and show considerable activity against more resistant bacterial spores [35]. It was also observed that doping of $\mathrm{ZnO}$ NPs with other metals such as gold, silver, iron etc. improved the antimicrobial activity of $\mathrm{ZnO}$ NPs [36-37]. Also, inhibitory effects of $\mathrm{ZnO}$ NPs are correlated with their size and concentration, with smaller particles offering better inhibitions in higher concentrations [38-39].

\section{Zinc Oxide Nanoparticles}

Zinc oxide $(\mathrm{ZnO})$ is a class of inorganic metal oxides available and exhibit a wide range of nanostructures. It is known as II-VI semiconductor [40], since $\mathrm{Zn}$ and $\mathrm{O}$ are classified two and six in the periodic table, respectively. It is characterized by a direct wide band gap $(3.3 \mathrm{eV})$ in the near-UV spectrum, a high excitonic binding energy (60 meV) at room temperature [41-45], and a natural n-type electrical conductivity [46].

Though $\mathrm{ZnO}$ shows light covalent character, it has very strong ionic bonding in the $\mathrm{Zn}-\mathrm{O}$. Its longer durability, higher selectivity, and heat resistance are preceded than organic and inorganic materials [47]. The synthesis of nano-sized $\mathrm{ZnO}$ has led to the investigation of its use as new antibacterial agent.

Lower cost, large surface area, white appearance and their remarkable applications in the more fields are the advantages of $\mathrm{ZnO}$ nanoparticles. Interestingly, $\mathrm{ZnO}-\mathrm{NPs}$ are reported by several studies as non-toxic to human cells [48], this aspect necessitated their usage as antibacterial agents, harmful to microorganisms, holding good biocompatibility to human cells [39].

ZnO-NPs exhibit attractive antibacterial properties due to the increased specific surface area as the reduced particle size leading to enhanced particle surface reactivity. $\mathrm{ZnO}$ is a bio-safe material that possesses photo-oxidizing and photocatalysis impacts on chemical and biological species. Emphasize was given to bactericidal and bacteriostatic mechanisms with focus on generation of reactive oxygen species (ROS) including hydrogen peroxide $\left(\mathrm{H}_{2} \mathrm{O}_{2}\right), \mathrm{OH}^{-}$ (hydroxyl radicals), and $\mathrm{O}_{2}^{-2}$ (peroxide). ROS has been a major factor for several mechanisms due to the electrostatic binding of the particles on the microbial surface contributing to the antimicrobial activity of $\mathrm{ZnO}$ nanoparticles [49].

Photocatalytic activity of $\mathrm{ZnO}$ nanoparticles offers a promising method for wasted water treatment [50]. Toxic water pollutants released from textile and dying industries by utilizing natural source of energy, sunlight is degraded by $\mathrm{ZnO}$ and exhibit photochemical reactivity. This could be because of the presence of many active sites and fabrication of hydroxyl radicals on $\mathrm{ZnO}$ surface. They exhibit high catalytic efficiency, strong adsorption ability, being used in sunscreens manufacture [51], ceramics and rubber processing, wastewater treatment, and fungicide [52-53]. $\mathrm{ZnO}$ nanoparticles can absorb both UV-A and UV-B radiation and therefore offers better protection and improved opaqueness [52].

\subsection{ZnO nanoparticles green synthesis}

$\mathrm{ZnO}$ nanoparticles have been reported to be synthesized from many plant extracts. In Azadirachta indica, stabilizing agents for the nanoparticle synthesis are flavanones, terpenoids and reducing sugars, the constituents of the Neem leaf broth [4]. It is suggested that the aldehyde groups are responsible for reduction of zinc oxide to zinc oxide nanoparticles and stabilize the nanoparticles [4].

Noorjahan et al. proposed a method to synthesize zinc oxide nanoparticles from the leaf extract of Azadirachta indica and lipseste un verb its characterization by FTIR and SEM analysis. It was seen that from FTIR analysis, alcohols, terpenoids ketones, aldehydes and carboxylic acid were surrounded by synthesized nanoparticles. SEM analysis showed stable zinc oxide nanoflakes and spindle shaped nanoparticles. The size of the $\mathrm{ZnO}$ nanoparticles synthesized was found to be $50 \mu \mathrm{m}$ [54].

Sangeethaa et al., depict Aloe vera has immunomodulatory, anti-inflammatory, UV protective, antiprotozoal, and wound- and burn-healing promoting properties. Single crystalline triangular gold nanoparticle ( $\sim 50-350 \mathrm{~nm}$ in size) and spherical silver nanoparticles $(\sim 15 \mathrm{~nm}$ in size $)$ in high yield have been successfully synthesized [55]. This synthesis is by the reaction of aqueous metal source ions (chloroaurate ions for $\mathrm{Au}$ and silver ions for $\mathrm{Ag}$ ) with the extract of the Aloe vera plant. Aloe vera extract was used to synthesize Spherical zinc oxide nanoparticles and their optical properties were studied [55].

Murraya koenigii has been reported to have hypoglycemic [56] and anti-fungal effects [57] and against colon carcinogenesis [58]. The plant has active agents like polyphenols and flavonoids, which have strong roles in the synthesis and stabilization of metal NPs [59-61]. The other authors reported that 
the contents of polyphenol and flavonoids present in the leaf of M. koenigii are $81.9 \mathrm{mg}$ Gallic acid equivalent $\mathrm{g} / \mathrm{L}$ and $39.98 \mathrm{mg}$ of quercetin $\mathrm{g} / \mathrm{L}$, respectively. These compounds act as reducing agents and as the stabilizing agents by adhering on the surface of the NPs formed, and thereby prevent their aggregation and control the particle size [59-61].

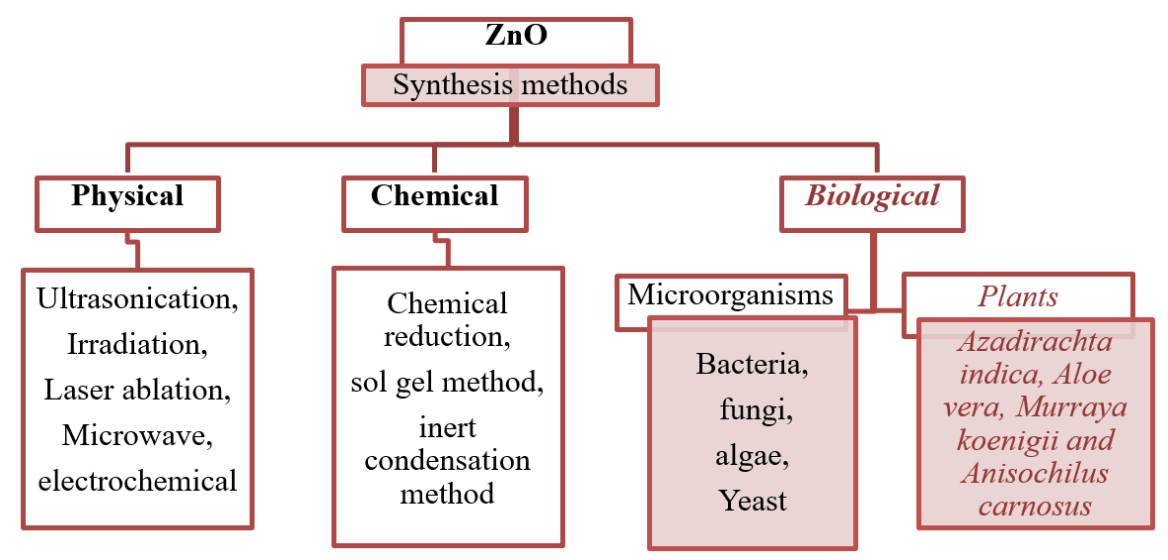

Fig. 1. Methods involving nanoparticle synthesis

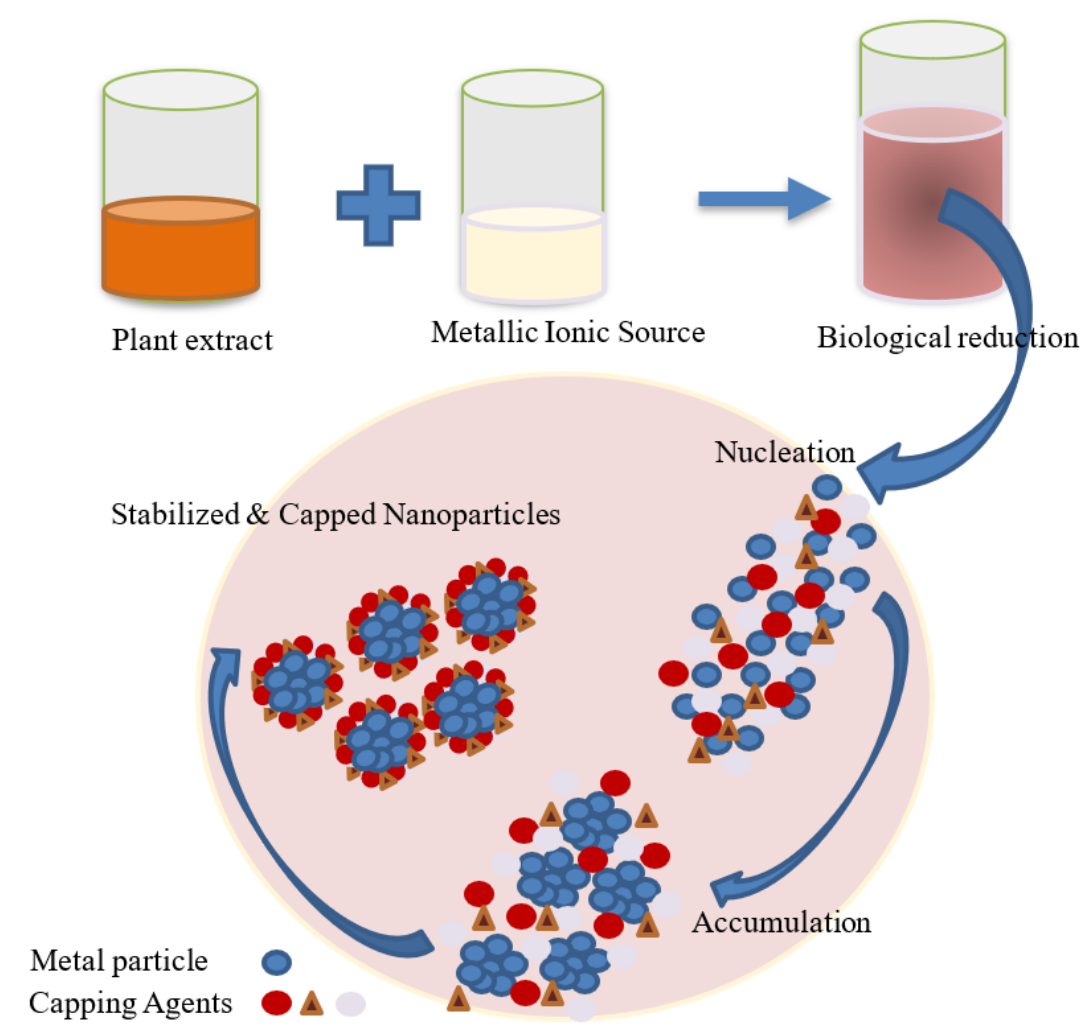

Fig. 2. Schematic representation of mechanism for biological synthesis of nanoparticles using plant extract

\subsection{Antibacterial activity of $\mathrm{ZnO}$ nanoparticles}

Elumalai and Velmurugan reported the MIC, MBC and MFC values of prepared $\mathrm{ZnO}$ NPs against bacteria and fungi. Significant inhibition by the $\mathrm{ZnO}$
NPs was seen against S. aureus, B. subtilis, P. aeruginosa, P. mirabilis and E. coli and fungi strains such as C. albicans and C. tropicalis with distinct differences in the susceptibility to ZnO NPs in a dose dependent manner. Among them, S. aureus was found to be more susceptible to $\mathrm{ZnO}$ NPs [62]. 
The mean zones of inhibition ranged from $9.8 \pm$ 0.76 to $23 \pm 0.50(\mathrm{~mm})$. The highest mean zones of inhibition ranged from $14.4 \pm 0.76$ to $23 \pm 0.50$ (mm) against $\mathrm{S}$. aureus. The MIC values ranged between to 6.25 to $50(\mu \mathrm{g} / \mathrm{mL})$ and $\mathrm{MBC}$ and MFC from 12.5 to $50(\mu \mathrm{g} / \mathrm{mL})$.

Antimicrobial activities of $\mathrm{ZnO}$ NPs increased with increase of concentrations (50, 100 and 200 $\mu \mathrm{g} / \mathrm{mL}$ ) and were due to the increase of $\mathrm{H}_{2} \mathrm{O}_{2}$ concentration on the surface of $\mathrm{ZnO}$.

Lakshmi et al. have reported the antibacterial study of zinc oxide nanoparticles synthesized from Aloe vera hot extract $(\mathrm{ZnO}-\mathrm{AH})$, cold extract $(\mathrm{ZnO}$ $\mathrm{AC})$ and chemical method $(\mathrm{ZnO}-\mathrm{C})$ on six clinically isolated strains namely, Bacillus subtilis, Escherichia coli, Klebsiella pneumoniae, Pseudomonas aeruginosa, Salmonella typhi and Staphylococcus aureus. Significant activity was seen in the zinc oxide particles synthesized by chemical method and particles obtained using Aloe vera cold extract. $\mathrm{ZnO}-$ AH showed less activity.

There was a significant difference in the antibacterial activities of $\mathrm{ZnO}-\mathrm{AH}$ and $\mathrm{ZnOAC}$ though both synthesized in a similar manner. This variation was because of the size as the size of $\mathrm{ZnO}$ $\mathrm{AH}$ is much more than that of $\mathrm{ZnO}-\mathrm{AC}$. The smaller the size of nanoparticles, the better is their activity [63-64].

Mariam et al., reported a novel synthesis for $\mathrm{In}_{2} \mathrm{O}_{3}$ and $\mathrm{ZnO}$ nanoparticles with particle sizes in the range of 10 to $30 \mathrm{~nm}$ using indium nitrate and zinc nitrate solutions. They utilized A. vera extract as a solvent instead of organic solvents. The antibacterial and antifungal activities of the particles were studied using S. aureus, S. pyogenes, P. aeruginosa, E. coli, and S. typhi and the fungal strains were A. niger, A. flavus, A. fumigatous, Rhizopus indicus and Mucor indicus. Highest inhibitory activity against the tested bacteria was displayed by the extracts with $\mathrm{ZnO}+$ $\mathrm{In}_{2} \mathrm{O}_{3}+$ A. vera. A. bigger growth was also inhibited by the extract. It was concluded that $\mathrm{ZnO}$ nanoparticles mixed with $A$. vera were effective in inhibiting bacterial growth [65].

Elumalai et al., reported that to study the antimicrobial activity of the leaf extract of Murraya koenigii the bio-assay was carried out using five bacterial strains such as S. aureus, B. subtilis, P. aeruginosa E. coli, P.mirabilis and two fungal strains such as C. albicans and C. tropicalis as per the disc diffusion and dilution technique. It was concluded that the zone of inhibition increased with increase in zinc oxide nanoparticle concentration and decrease in particle size. The $\mathrm{ZnO}-\mathrm{NPs}$ were found to be effective for both S. aureus and E. coli and P.aeruginosa [62].

Anbuvannan et al. reported the $\mathrm{ZnO}$ nanoparticle synthesis and antibacterial activity of Anisochilus carnosus. Antibacterial activity was studied against the Gram-negative and the Grampositive bacteria $\mathrm{S}$. paratyphi, V. cholerae, S. aureus, and E. coli. Inhibition zones of $6 \mathrm{~mm}, 10 \mathrm{~mm}, 7 \mathrm{~mm}$ and $9 \mathrm{~mm}$ were observed from the synthesized $\mathrm{ZnO}$ nanoparticles against S. paratyphi, V.cholerae, S. aureus, and E. coli, respectively. In the present study, green synthesized $\mathrm{ZnO}$ NPs exhibited a greater significant zone of inhibition compared to leaf extract and solvent [66].

\section{Conclusions}

The green synthesis of $\mathrm{ZnO}$ nanoparticles is an interesting subject of Nanomaterials Science. Also, of the latest concern it is the biosynthesis of metal nanoparticles using plants to obtain them on a large scale. Nanoparticles produced by plants are more stable and more varied in shape and size in comparison to those produced by other organisms. In this review, the synthesis of $\mathrm{ZnO}$ nanoparticles and antimicrobial activity were reported. The $\mathrm{ZnO}$ nanoparticles have varied applications in all fields. The enhanced bioactivity of $\mathrm{ZnO}$ nanoparticles is attributed to the higher surface area to volume ratio. The antimicrobial activity of $\mathrm{ZnO}$ nanoparticles was reported with respect to Azadirachta indica, Aloe vera, Murraya koenigii and Anisochilus carnosus. Therefore, based on the reported antibacterial and antifungal activity, it can be concluded that the $\mathrm{ZnO}$ nanoparticles constitute an effective antimicrobial agent against pathogenic microorganisms.

\section{References}

[1]. Moritz M., Moritz M. G., Chem. Eng. J., 228, p. 596-613, 2013.

[2]. Rajiv P., Rajeshwari S., Venckatesh R., Spectrochim. Acta A, 112, p. 384-387, 2013.

[3]. Caruthers S. D., Wickline S. A., Lanza G. M., Curr. Opin. Biotechnol., 18, p. 26-30, 2007.

[4]. Nath D., Banerjee P., Environ. Toxicol. Pharmacol, 36, p. 997-1014, 2013.

[5]. Salam H. A., Rajiv P., Kamaraj M., Jagadeeswaran P., Gunalan S., Sivaraj R., Int. Res. J. Biol. Sci., 1, p. 85-90, 2012.

[6]. Rajiv P., Rajeshwari S., Venckatesh R., Spectrochim. Acta A, 112, p. 384-387, 2013.

[7]. Dijiken A. V., Meulenkamp E. A., Vanmaekelbergh D., Meijerink A., J. Lumin, 90, p. 123-128, 2000.

[8]. Singhal G., Riju B., Ashish R. S., Rajendra P. S., Adv. Sci. Eng. Med., 4, p. 62-66, 2012.

[9]. Mason C., Vivekanandhan S., Misra M., Mohanty A. K., World J. Nano Sci. Eng., 2, p. 47-52, 2012.

[10]. Chandran S. P., Chaudhary M., Pasricha R., Ahmad A., Sastry M., Biotechnol. Prog., 22, p. 577-583, 2000.

[11]. Shankar S. S., Rai A., Ahmad A., Sastry M., J. Colloid Interface Sci., 275, p. 496-502, 2004.

[12]. Huang J., Li Q., Sun D., Lu Y., Su Y., Yang X., et al., Nanotechnology, 18, p. 105-104, 2007.

[13]. Jamdagni P., Khatri P., Rana J. S., Int. Nano Lett., 6, p. 139-146, 2016.

[14]. Syed M. A., Biosens. Bioelectron., 51, p. 391-400, 2014. 
[15]. Bobo D., Robinson K. J., Islam J., Thurecht K. J., Corrie S. R., Pharm. Res., 33 (10), p. 2373-2387, 2016.

[16]. Chen G., Roy I., Yang C., Prasad P. N., Chem. Rev., 116, p. 2826-2885, 2016.

[17]. Ahmed S., Ahmad M., Swami B. L., Ikram S., J. Adv. Res., 7 (1), p. 17-28, 2016.

[18]. Sirelkhatim A., Mahmud S., Seeni A., Kaus N. H. M., Ann L. C., Bakhori S. K. M., Hasan H., Mohamad D., Nano-Micro Lett., 7, p. 219-242, 2015.

[19]. Diallo A., Mothudi B. M., Manikandan E., Maaza M., J. Nanophotonics, 10, p. 26010, 2016a.

[20]. Diallo A., Manikandan E., Rajendran V., Maaza M., J. Alloys Compd., 681, p. 561-570, 2016b.

[21]. Sone B. T., Manikandan E., Gurib-Fakim A., Maaza M., J. Alloys Compd., 650, p. 357-362, 2015.

[22]. Thovhogi N., Park E., Manikandan E., Maaza M., GuribFakim A., J. Alloys Compd., 655, p. 314-320, 2016.

[23]. Eslami A., Amini M. M., Yazdanbakhsh A. R., MohseniBandpei A., Safari A. A., Asadi A. N., J. Chem. Technol. Biotechnol., 91, p. 2693-2704, 2016.

[24]. Thema F. T., Manikandan E., Gurib-Fakim A., Maaza M., J. Alloys Compd., 657, p. 655-661, 2016.

[25]. Mohammad V., Umar A., Hahn Y. B., American Scientific Publishers, USA, p. 1-36, 2010.

[26]. Rosi N. L., Mirkin C. A., Chem. Rev., 105 (4), p. $1547-$ $1562,2005$.

[27]. Husen A., Siddiqi K. S., J. Nanobiotechnol., 12, p. 28, 2014a.

[28]. Husen A., Siddiqi K. S., Nanoscale Res. Lett., 9, p. 229, 2014 b.

[29]. Jeevanandam J., Chan Y. S., Danquah M. K., ChemBioEng Rev., 3, p. 55-67, 2016.

[30]. Shanker U., Jassal V., Rani M., Kaith B. S., Int. J. Environ Anal. Chem., 96 (9), p. 801-835, 2016.

[31]. Singh P., Kim Y. J., Zhang D., Yang D. C., Trends Biotechnol., 34 (7), p. 588-599, 2016.

[32]. Espitia P. J. P., Soares N. F. F., Coimbra J. S. R., De Andrade N. J., Cruz R. S., Medeiros E. A. A., Food Bioprocess Technol., 5, p. 1447-1464, 2012.

[33]. Franklin N. M., Rogers N. J., Apte S. C., Batley G. E., Gadd G. E., Casey P. S., Environ. Sci. Technol., 41 (24), p. 84848490, 2007.

[34]. Li Q., Mahendra S., Lyon D. Y., Brunet L., Liga M. V., Li D., Alvarez P. J., Water Res., 42 (18), p. 4591-4602, 2008.

[35]. Azam A., Ahmed A. S., Oves M., Khan M. S., Habib S. S., Memic A., Int. J. Nanomed., 7, p. 6003-6009, 2011.

[36]. Jime'nez A. B. P., Aguilar C. A. H., Ramos J. M. V., Thangarasu P., Aust. J. Chem., 68, p. 288-297, 2015

[37]. Shah A. H., Manikandan E., Basheer Ahamed M., Ahmad Mir D., Ahmad Mir S., J. Lumin., 145, p. 944-950, 2014.

[38]. Buzea C., Pacheco I. I., Robbie K., Biointerphases, 2, p. MR17-MR71, 2007.

[39]. Padmavathy N., Vijayaraghavan R., Sci. Technol. Adv. Mat., 9, p. 1-7, 2008.

[40]. Gertrude Neumark Y. G., Kuskovsky I., in Springer Handbook of Electronic and Photonic Materials, ed. by P.C. Safa Kasap Springer, p. 843-854, 2007.

[41]. Wang Z. L., J. Phys.: Condens. Matter., 16 (25), p. R829 R858, 2004.
[42]. Wang Z. L., Song J., Science, 312 (5771), p. 242-246, 2006

[43]. Janotti A., Van de Walle C. G., Rep. Prog. Phys., 72 (12), p $126501,2009$.

[44]. Zhang Y., Ram M. K., Stefanakos E. K., J. Nanomater., p. $1-22,2012$.

[45]. Schmidt-Mende L., MacManus-Driscoll J. L., Mater. Today, 10 (5), p. 40-48, 2007

[46]. Wellings J., Chaure N., Heavens S., Dharmadasa I., Thin Solid Films, 516 (12), p. 3893-3898, 2008.

[47]. Amna Sirelkhatim, Shahrom Mahmud, Azman Seeni, Noor Haida Mohamad Kaus, Ling Chuo Ann, Siti Khadijah Mohd Bakhori, Habsah Hasan, Dasmawati Mohamad, Nanomicro Lett., 7 (3), p. 219-242, 2015.

[48]. Colon G., Ward B. C., Webster T. J., Increased osteoblast and decreased Staphylococcus epidermidis functions on nanophase $\mathrm{ZnO}$ and $\mathrm{TiO}_{2}$, J. Biomed. Mater. Res., 78 (3), p. 595-604, 2006.

[49]. Zhang L., Jiang Y., Ding Y., Povey M., York D., J. Nanoparticle Res., 9, p. 479-489, 2007.

[50]. Srinivasa B. Reddy, Krishna V., Veni K., Ravindhranath K., J. Chem. Pharm. Res., p. 4682-4694, 2012.

[51]. Seshadri R., Rao C. N. R., Muller A., Cheetham A. K., Wiley-VCH Verlag GmbH, Weinheim, vol. 1, p. 94-112, 2004

[52]. Theodore L., Nanotechnology: Basic Calculations for Engineers and Scientists, Wiley, Hoboken, 2006.

[53]. Wang X., Lu J., Xu M., Xing B., Environmental Science and Technology, 42, p. 7267-7272, 2008.

[54]. Noorjahan C. M., Jasmine Shahina S. K., Deepika T., Summera Rafiq. International Journal of Scientific Engineering and Technology Research, 04 (30), p. 5751-5753, 2015.

[55]. Sangeethaa G., Rajeshwaria S., Venckateshb R., Materials Research Bulletin, 46, p. 2560-2566, 2011.

[56]. Khan B. A., Abraham A., Leelamma S., Indian J. Bio Chem. Biophys, 32, p. 106-108, 1995.

[57]. Das K. C., Chakraborty D. P., Bose P. K., J. Spreng, Experientia, 21, p. 340-345, 1965.

[58]. Khan B. A., Abraham A., Leelamma S., Investig. New Drugs, 14, p. 365-369, 1996.

[59]. Roy N., Alam M. N., Mondal S., Sk I., Laskar R. A., Das S., Mandal D., Begum N. A., Process Biochem, 47 (9), p. 13711380, 2012

[60]. Roy N., Mondal S., Laskar R. A., Basu S., Mandal D., Begum N. A., Biog. Colloids Surf. B, 76 (1), p. 317-325, 2010. [61]. Alam M. N., Das S., Batuta S., Roy N., Chatterjee A., Mandal D., Begum N. A., ACS Sustain. Chem. Eng., 2, p. 652664, 2014.

[62]. Elumalai K., Velmurugan S., Applied Surface Science, 345 , p. 329-336, 2015

[63]. Yamamoto O., Int. J. Inorgan. Mater, 3, p. 643-646, 2001.

[64]. Makhluf S., Dror R., Nitzan Y., Adv. Func. Mater., 15, p. 1708-1715, 2005.

[65]. Mariam M. Kashif A. A., Arokiyaraj S., Bououdina M., Sankaracharyulu M. G. V., Jayachandran M., Hashim U., Digest Journal of Nanomaterials and Biostructures, 9 (3), p. 10071019, 2014.

[66]. Anbuvannan M., Ramesh M., Viruthagiri G., Shanmugam N., Kannadasan N., Spectrochim Acta A Mol Biomol Spectrosc., 143, p. 304-308, 2015. 